\title{
Challenging poverty with green space in informal settlements of Quito
}

\author{
Desafiando a pobreza com espaços verdes em assentamentos informais de Quito \\ Desafiando la pobreza con espacios verdes en asentamientos informales de Quito
}

Received: 01/10/2021 | Reviewed: 01/11/2021 | Accept: 01/12/2021 | Published: 01/13/2021

\author{
Ignacio Loor \\ ORCID: https://orcid.org/0000-0003-4806-1032 \\ Universidad San Gregorio de Portoviejo, Ecuador \\ E-mail: iwloor@sangregorio.edu.ec \\ Lucía Rivadeneira \\ ORCID: https://orcid.org/0000-0001-5989-7703 \\ The University of Manchester, United Kingdom \\ E-mail: lucia.rivadeneirabarreiro@manchester.ac.uk \\ Julio Rivadeneira \\ ORCID: https://orcid.org/0000-0002-9494-7494 \\ Universidad Técnica de Manabí, Ecuador \\ E-mail: julio.rivadeneira@utm.edu.ec
}

\begin{abstract}
Planners increasingly recognize the value of green spaces to the wellbeing of urban residents. Research on ecosystem services has produced much of what is known about such value, although the attention is mainly on the cities' core while informal settlements remain overlooked. Using a case study of informal settlements in Quito, this paper focuses on how their residents use the neighboring green space to fight poverty. The study uses data from interviews, field notes, and archives to show how green spaces escalate the capabilities of the neighboring residents to access everyday resources. A preserved landscape enhances the ability to walk and travel to everyday destinations; allotments reduce the reliance on debts with shop keepers to access food; and sports fields enable income generation and pursue a career. These findings provide an understanding of how to address simultaneously environmental, social, and economic challenges in cities of developing countries. Planners engaged in the sustainable development agenda would benefit from this research.
\end{abstract}

Keywords: Green spaces; Informal settlements; Urban poverty.

\section{Resumo}

Os planejadores reconhecem cada vez mais o valor dos espaços verdes para o bem-estar dos residentes urbanos. A pesquisa sobre serviços ecossistêmicos produziu muito do que se sabe sobre esse valor, embora a atenção esteja principalmente no centro das cidades enquanto os assentamentos informais permanecem ignorados. Usando um estudo de caso de assentamentos informais em Quito, este artigo se concentra em como os residentes usam as áreas verdes vizinhas para combater a pobreza. O estudo usa dados de entrevistas, notas de campo e arquivos para mostrar como os espaços verdes aumentam a capacidade dos residentes vizinhos de acessar os recursos diários. Uma paisagem preservada aumenta a capacidade de caminhar e viajar para destinos diários; fazendas urbanas reduzem a dependência de dívidas com lojistas para ter acesso aos alimentos; e os campos esportivos possibilitam a geração de renda e o prosseguimento da carreira. Essas descobertas fornecem uma compreensão de como lidar simultaneamente com os desafios ambientais, sociais e econômicos em cidades de países em desenvolvimento. Os planejadores engajados na agenda de desenvolvimento sustentável se beneficiariam com esta pesquisa.

Palavras-chave: Espaços verdes; Assentamentos informais; Pobreza urbana.

\section{Resumen}

Los planificadores reconocen cada vez más el valor de los espacios verdes para el bienestar de los residentes urbanos. La investigación sobre los servicios de los ecosistemas ha producido gran parte de lo que se conoce sobre ese valor, aunque la atención se centra en el centro de las ciudades mientras los asentamientos informales han permanecido ignorados. Usando un estudio de caso de asentamientos informales en Quito, este documento se enfoca en cómo los residentes usan los espacios verdes vecinos para combatir la pobreza. El estudio utiliza datos de entrevistas, notas de campo y archivos para mostrar cómo los espacios verdes aumentan las capacidades de los residentes vecinos para acceder a los recursos cotidianos. Un paisaje preservado mejora la capacidad de caminar y viajar a destinos cotidianos; los huertos reducen la dependencia de crédito con los proveedores de alimentos locales; y las canchas deportivas permiten generar ingresos y desarrollar una carrera profesional. Estos hallazgos proporcionan una comprensión de cómo abordar simultáneamente los desafíos ambientales, sociales y económicos en las ciudades de los países en desarrollo. Los planificadores comprometidos con la agenda de desarrollo sostenible se beneficiarían de esta investigación.

Palabras clave: Espacios verdes; Asentamientos informales; Pobreza urbana. 


\section{Introduction}

This study shows how green space can help fight poverty in informal settlements of Latin America, a region where larger cities feature sprawled expansion, deep social fragmentation and marked inequalities in access to everyday resources (Abad \& Lindert, 2017). Though the sustainable development narrative is progressively mobilizing initiatives to enhance environmental quality and wellbeing in cities throughout the region (Crespo et al., 2016; Jordán et al., 2003), the extent to which these benefit the urban poor and marginalized communities remains questionable. Instead, practices aiming to address environmental and development issues of cities seem exclusionary. For example, much of the infrastructure standing in informal settlements, including green spaces, results from their own collective efforts.

For the purpose of this paper, green spaces can be any permeable space covered with vegetation, which is embedded within built environments and support social interaction. Much of what is known about green spaces is based on the ecosystem services framework (Costanza et al., 1997). Studies of the last decade from this analytical lens concerns mainly issues of physical and mental wellbeing to urban residents (Thompson et al., 2012); however, too little attention has been paid to the residents of informal settlements. On the other hand, defining poverty is often problematic (Hagenaars \& De Vos, 1988). This paper takes inspiration in Amartya Sen's notion of development as freedoms (Sen, 2001) to addresses poverty not only as a problem of insufficient income and material resources, but as a systemic set of constraints that hold the urban poor from taking part fully in the social security system, including the city's cultural life.

The literature on urban poverty and ecosystem services has overlooked green spaces of informal settlements. Meanwhile, development scholars have focused on how technologies materialize to enable access to water, electricity, streetlights, pavements and roads (McIntosh et al., 2013). Choguill (1996) differentiates these latter in two: those resulting from a formal provision, usually in form of basic infrastructure provided by governments; and those involving the articulation of the underserved communities themselves and non-governmental actors. Several scholars have referred to the latter as "on-site systems" (Lüthi et al., 2011; Mara, 1996; Mara \& Alabaster, 2008).

Concerning green spaces in the cities' peripheries, the scant literature addresses these as the low-cost alternative to address issues of stormwater runoff (Lossouarn et al., 2016; Milou, 2008), stream stabilization (Adegun, 2014) and wetland revival (Kaplan et al.,2004). These studies have addressed green spaces mainly as infrastructures formally provided rather than as spontaneously emerged on-site systems. Their primary concern has been the role that these spaces play in environmental issues of cities' cores rather than the wellbeing of people living nearby. Thus, whether green spaces can help resident of informal settlements to deal simultaneously with poverty and environmental pressures is unknown.

The argument that green spaces can support ecological functions in informal settlements (Motzny, 2015) suggests that this study can interest sustainable development scholars and urban planners. Drawing from critiques of sustainable development approaches, specifically the indifference of reported initiatives to cultural dimensions of development and alternative constructions of poverty (Briant, 2017; Haque, 2000; Horn, 2017; McMichael, 2011), this study explores how residents of informal settlements incorporate green spaces in their everyday life to challenge poverty.

We organize the rest of the paper as follows. The following section summarizes the methods of data collection and analysis. Next, we present the findings and discussion by showing how different forms of green spaces are helping residents of informal settlements to ease poverty. Finally, the paper offers a conclusion and some sign of future research.

\section{Methodology}

To investigate if green space supports poverty alleviation, we design a case study of informal settlements in Quito City. Case study is appropriate to produce descriptions that explain the green space/poverty nexus and inform policy makers about sustainable development approaches (Davidson-Hunt et al., 2017; Simons, 2009). “A case, to be considered as such, must be a 
phenomenon that has some special or differential characteristic that takes it out of the common place" (Pereira et al., 2018). The following three paragraphs explain why Quito makes a convenient case to address this gap.

Quito, the capital city of Ecuador, is on the Andes Mountains in equatorial South America. The city hosts about 2.7 million people, of whom some 50\% live in an informally settled neighborhood located on the slopes of volcano Pichincha and surrounding cordilleras (Jácome, 2017a). Similar to other Latin America cities, Quito municipality has improvised policies to address climate change and foster social inclusion since the last decade (Rueda Carrillo, 2015). Nonetheless, pressing issues of urban pollution, social fragmentation and marked inequalities remain (Alova \& Burgess, 2017).

Green space is not a priority for the municipal government. They argue that Quito is a significantly green city, since its 21,6 square meters per capita of green space (Jácome, 2017b) far exceed the 9 square meters minimum suggested by the World Health Organization to achieve healthy cities (WHO, 2012). However, a study by Verdesoto et al. (2009) on the perceptions of green space provision in Quito concluded that, because of the poor spatial distribution, the provision of green space is deemed deficient. This is particularly the case for residents of informal settlements.

The adoption of constitutional rights of nature in Ecuador since 2008 (Daly, 2012; Greene, 2011) and of emerging politics centered on aboriginal paradigms of living-well (Kauffman \& Martin, 2014; Radcliffe, 2012), also makes of Quito an auspicious case to explore the link green space/poverty. The living-well paradigm frames poverty and wellbeing within a set of non-monetary values, of which the relationship with the environment stands out. Similarly, concepts such as food sovereignty, socio-environmental justice, social empowerment, and the right to the city have gained ground during the last two decades (Becker, 2011; Clark, 2013; Horn, 2017). These cultural values provide a worthwhile exploring perspective of poverty alleviation.

Concerning data collection, since very little is known about green spaces in informal settlements of Quito, and no sampling frame actually exist (Denscombe, 2014), a snowball sampling approach was necessary in the beginning. The study focused on green spaces found in neighborhoods "La Roldós" and "La Pulida" in the northwest, and "La Ecuatoriana" and "El Rocío de Guamanî" in the city's south, as shown in the yellow circles in Figure 1. These neighborhoods emerged informally in the 1980s, although by now, they achieved partial integration into the city's public infrastructure networks. Green spaces in these neighborhoods often take the form of restored segments of ravines, food producing allotments, and sports fields (basically for football and volleyball of three).

Figure 1. Informal settlements investigated.

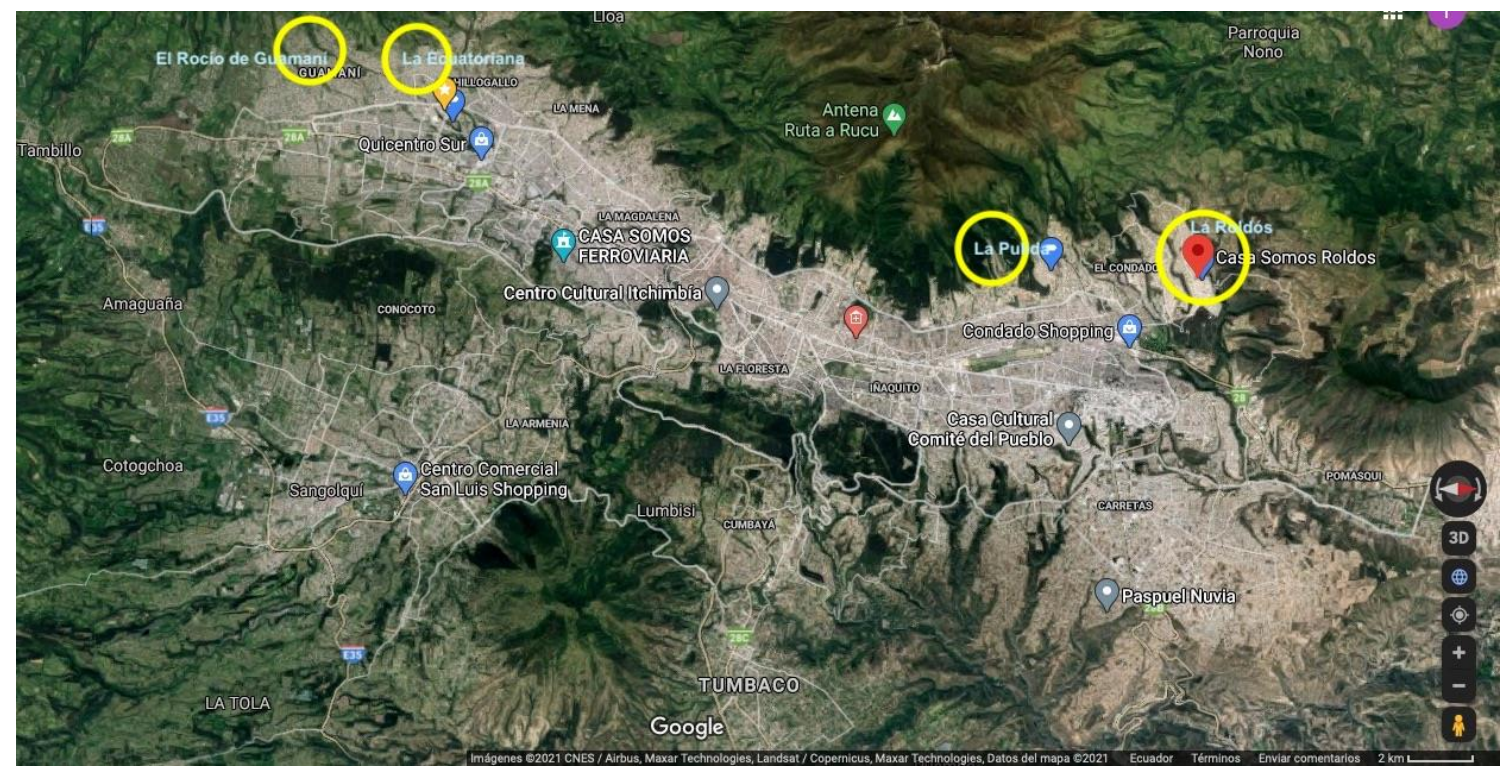

Source: Google maps. 
As for instruments of data collection, the study involved interviews, observations, and documents analysis between June 2017 and February 2018. Thus, the raw data took the form of narratives, field notes, and documents' summaries. Preserving the voices of the 60 residents interviewed was crucial in this research. They represent the authentic stories that are seldom heard in policy making (Mitlin \& Satterthwaite, 2013). It is the residents' knowledge about how crucial their green spaces are to produce wellbeing and overcome their everyday hardships of poverty what makes this study a novel contribution. The observations and interviews were conducted on the green spaces explored, while the interviewees were using them. As for the documents, we analyzed content about green spaces in informal settlements on newspapers El Comercio and Últimas Noticias of between January 2015 and September 2017. Finally, for data analysis, we used software NVivo and conducted iterative refinements to formulate the arguments presented in the findings' section ahead. Finally, for the analysis of narratives, we used a phenomenological stance (Hycner, 1985) to capture the meanings of wellbeing that they associate to green spaces.

\title{
3. Results and Discussion
}

\subsection{Restored segments of ravines.}

Most residents of the informal settlements investigated for this work walk from their homes to major roads and public transport stations every day. In doing so, the neighboring green landscape, featured by steep slopes and deep ravines, become means for allowing mobility to their ordinary destinations. Often, walking is the faster and inexpensive alternative to taking the bus or vehicles that provide informal transport to the city. At least, this is true for people living near a preserved segment of ravines, such as the one between neighborhoods La Ecuatoriana and Ciudadela del Ejército.

\begin{abstract}
"My wife wakes up at 4:30am. She prepares breakfast and the uniforms for the children to go to school. Children wake up at 5:45am. They have to be at school at 7am. My wife is self-employed. She is a seamstress and has the workshop at home. Most of her customers are dressmakers and tailors in the city center, so she normally goes to their workshops to take orders and deliver her work. The children's school is about 2 Km away from home. Going there involves walking down the slope and crossing the bridge over ravine Calicanto. For families with children, to afford the day they need to wake up between 4 and 5am..." (Resident of La Ecuatoriana, personal interview, 13th January 2018).
\end{abstract}

To appraise the relevance of restored ravines to poverty alleviation, it is necessary to consider that Quito has a marked monocentric configuration. The space referred by locals to as the hyper-center features most of the urban infrastructure value of the city, as well as the equipment, schools, marketplaces, and jobs. For residents of the core city and those of informal settlements alike, this is by far the most frequent destination every day. Thus, this space concentrates most of the income-earning opportunities.

However, since informal settlements are far and hardly connected to the city core, the restricted ability of their residents to reach the hyper center every day makes up a key driver of persistent poverty. Also, the course of densification and continuous emergence of gated communities in the peripheries constantly diverges the practices of commuting and isolate informal settlements. This is problematic in that communities with constrained accessibility experience limited access to opportunities needed to be socially and economically included in the wider urban culture.

Yet, for residents of informal settlements, reaching the hyper center is a widespread routinised practice, which involves adding a combination of multiple and contested under supplied means of mobility. Understanding the incremental and assembling nature of their commuting practices helps expose the role that a restored and well-preserved landscape play in the economy of these communities. Figure 2 gives an indication of how the residents re-configure the preserved segments of ravines by adding artefacts for mobility. 
Figure 2. Bridge over restored ravine "Habas Corral" in "La Pulida".

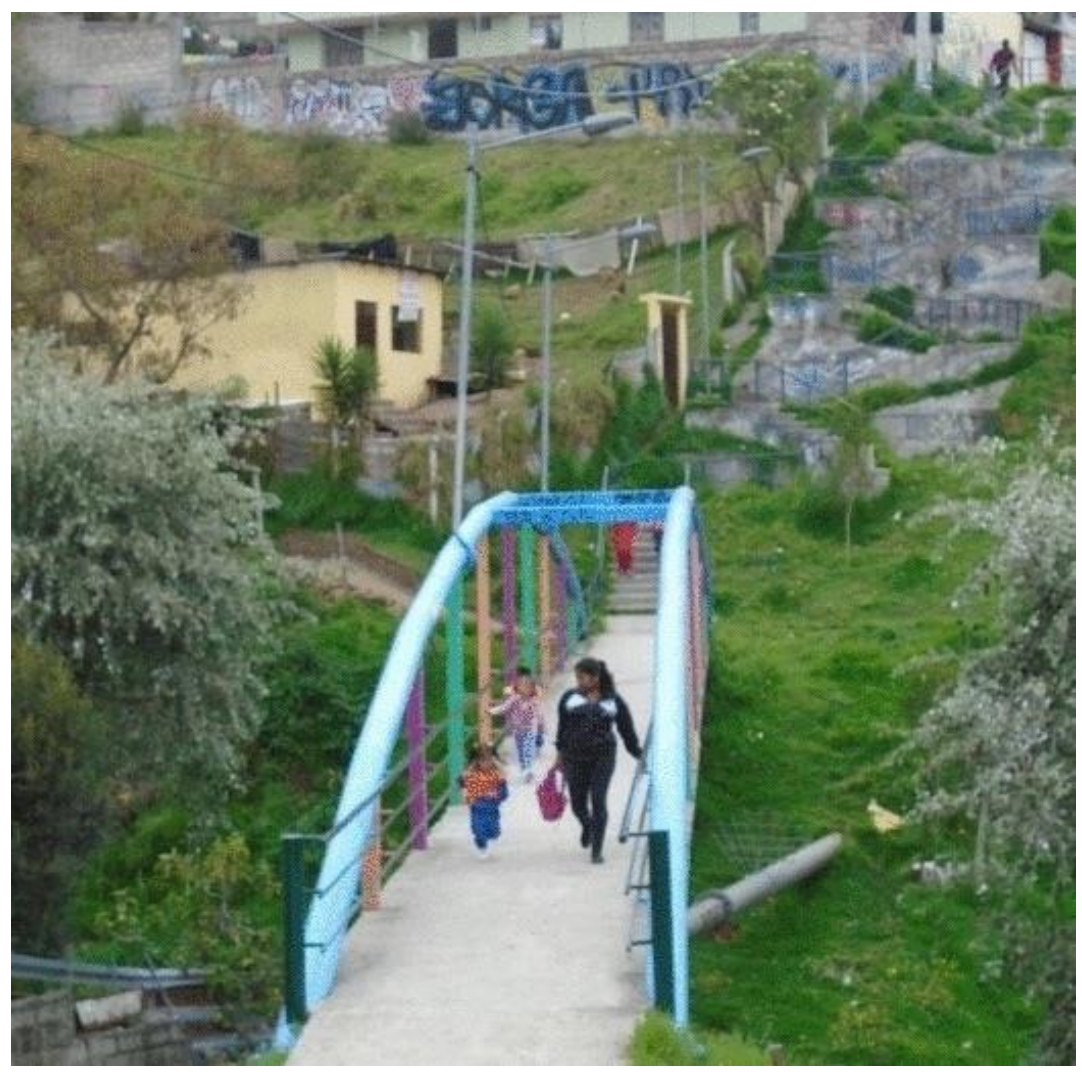

Source: Authors.

The effort that residents of informal settlements put in preserving and reconfiguring the surrounding green landscape by improvising bridges, footpaths, and stairways reflects the value of these green spaces to the mobility and economic life of these communities. Thus, where the landscape is preserved, walking is often a more convenient way of traveling in terms of time and budget. However, walking is rarely an option when it rains or when ravines are highly polluted. This suggests that by restoring and preserving the surrounding green landscape, the city can address both ecological challenges citywide, and economic challenges for the marginalized communities.

\subsection{Food Producing Allotments.}

Producing food in improvised allotments for self-consumption and income generation is a consistent practice throughout informal settlements, although the scale of the practice varies from one settlement to another. When single households own the allotments, these are often on their backyards or a nearby uninhabitable space such as the flank of a ravine. Yet, it is also common that allotments are community-owned and operated, in which case they are on unbuilt privately owned plots. Also, they differ in terms of size. There are smaller than 20 square meters, and as big as 300 square meters.

Regardless of the ownership, be it a single household or a community, the allotments in the informal settlements investigated are often a family matter. Typically, household members engage in the production, consumption, and vending/swapping of the produce. Sometimes, residents of informal settlements engaged in the allotments are immigrants from a rural area and have some traditional agricultural skills. However, it is also common that some learnt the farming skills along the allotment's maturity.

The community owned allotments are most often governed and operated by women. These often emerged from a combination of local resources and the input of outsider actors such as NGO Children International and their program Seeds of 
Hope, corporation Holcim Ecuador and their Strategic Community Investment program, and government supported organizations such as Agrupar and Inti. These organizations have played a paramount role in transferring knowledge for farming and organizing practices of consumption, sharing, and vending. Figure 3 shows a community allotment promoted by Children International during a field visit.

“...My neighbor invited me to the workshop of Children International. We learnt to prepare the soil, build seedbeds with recycled materials, and plant... Now, we have an association and sell our produce in the city's farmers markets" (farmer of Guamani)

Figure 3. Community allotment in Guamani.

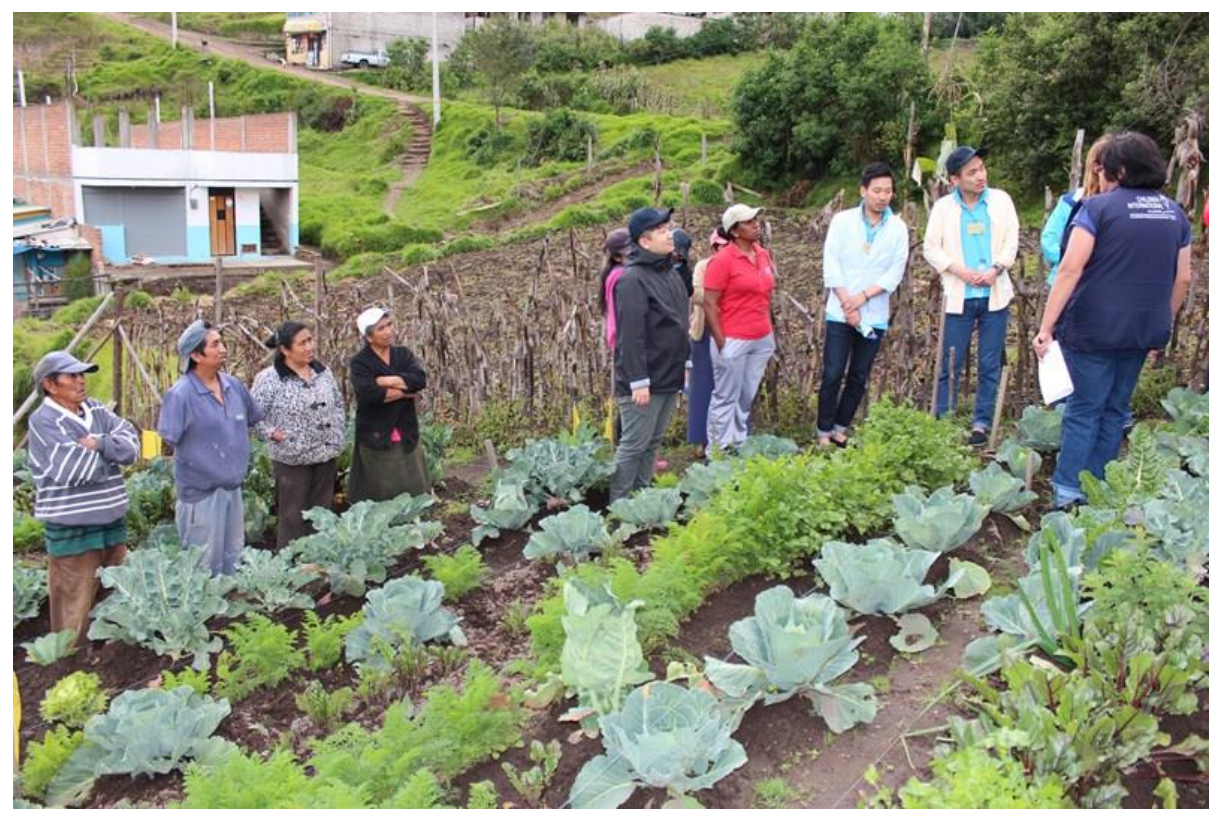

Source: Courtesy of Children International.

The literature has addressed widely the disadvantages for residents of informal settlements to take part in the formal job markets (Auyero, 2000; Davis, 2006; Rashid, 2009). Beyond the constraints to travel to the city every day, they also deal with the perceived stigma of living in violent environments and having low-quality instruction, which adds onto their disadvantageous condition to race for job opportunities in the hyper-center. This is especially pressing for women, who are more time-poor than males. In informal settlements, women perform a wide range of unpaid duties, such as taking children to school, or taking family members to healthcare facilities. These duties, while contribute to shape their social capital, also reinforce the time-wealth differences of gender, which erode their possibilities to undertake income-earning and self-constructive activities, and thus fight poverty.

Getting involved in food producing allotments is often one of such duties, although it allows for some income generation without the time constraints of a formal job. Yet, perhaps what is more relevant for poverty alleviation is that the allotments facilitate exchanging resources and enhancing the ability to feed household members. Engaging in the allotments substitute visits to the grocery shops and farmers' markets for procuring fresh food, for which farmers reduce their reliance on debt with shop owners to access food. These are all economic implications of green spaces in informal settlements, which policymakers can consider when planning for sustainable development. 


\subsection{Sports fields.}

Sports fields in informal settlements, especially for playing football and ecuavolley (volleyball of three played with a size 5 football), beyond leisure, serve both political and economic interests. Sports fields are permeable spaces between impervious surfaces, which shape collective capacity and empower residents of informal settlements for political bargaining. Also, at individual resident scale, the sports fields enable avenues to make income and build professional careers. Sports fields of informal settlements are green spaces that the neighboring residents spontaneously shape, sustain and progressively enhance.

Football and ecuavolley are popular and well-institutionalized sports in Quito. Football playing is organized in leagues, which are groups of competing teams formed within neighborhoods. Because of the popularity of the leagues, these make up channels for emergent politicians to engage residents of informal settlements in their proposals. This is not small, considering that about half the population of Quito lives in an informally developed neighborhood. Also, Quito has about 400 pitches of 350 non-professional leagues, where nearly 4800 games are played every week (El Telégrafo, 2014). The relationship between politicians and league leaders fosters a dynamic of exchanging votes for favors, which residents of informal settlements exploit to achieve legal titles over the land, basic infrastructure, and enhanced football pitches.

Also, the leagues have facilitated younger players and referees living in informal settlements to engage in the professional football league. Cases of local football stars that began their sports career in the neighborhood leagues are not few. Franklin Salas "the magician", for example, began his career in the league of San Miguel de los Bancos. He became professional and played for the National team. Internationally, he played in the Red Star Belgrade from Serbia and, during a trial period, in the PSV Eindhoven of Netherlands. So, it is normal that clubs playing in the professional league recruit young players in the informal settlements' leagues. Thus, the dynamics of the neighborhood leagues have helped residents of informal settlements to exit poverty, and for some, to achieve a dream of many.

“...Recruiters from clubs of the professional league come often to see the matches. Recently, the Club Deportivo El Nacional (football team of the professional league) tested 'Neymar' (an 11-year-old player nicknamed after the Brazilian forward of the Paris Saint-Germain) ..." (spectator of the league matches in Guamani)

Similarly, ecuavolley is a popular sport in Quito, although it is submerged in an informal betting system. Occasionally, spectators also take part in the betting pools. Ecuavolley is an everyday practice for many, which occurs from mid-afternoon in fields spread all-over the city, including informal settlements. The minimum bet per player in most popular ecuavolley fields is thirty dollars. However, in the fields that gather the most skillful players, such as in neighborhood Chimbacalle, and parks $E l$ Ejido, La Carolina and La Alameda in the hyper center, bets can go from 60 to 1500 dollars, per player per game. One player interviewed mentioned having bet 700 dollars on one occasion. The referee would usually make between 5 and $10 \%$ of the betting pool. Thus, ecuavolley can be a source of unregistered and continuous income, especially for the most skilled players. Figure 4 shows a well maintained football field in Guamaní and ecuavolley players in La Ecuatoriana deciding how much the bet. 
Figure 4. Football field in Guamani / Ecuavolley playing and betting in La Ecuatoriana.
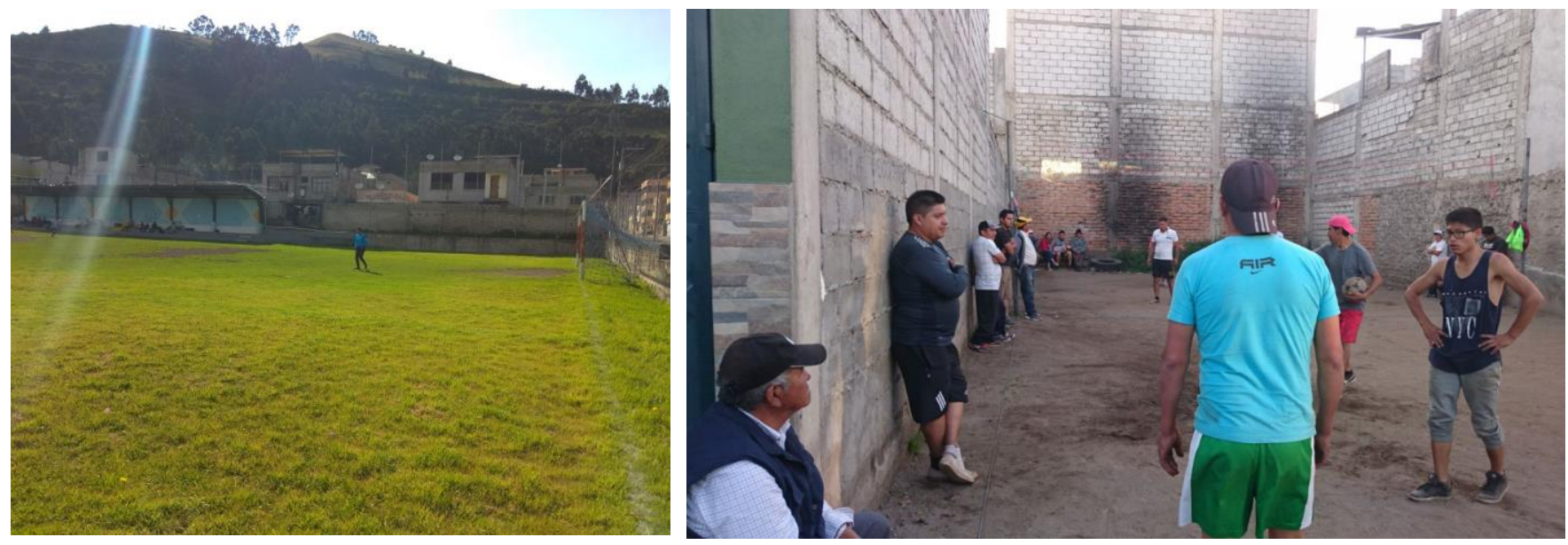

Source: Authors.

In sum, football and ecuavolley fields are important spaces in informal settlements, which, although not always vegetation covered, are most often permeable. Sports fields are relevant to alleviate poverty because they make up platforms from which to launch careers, create streams of income and opportunities, and produce political power that is functional to transform the space.

\section{Conclusion}

This paper showed how green spaces support poverty alleviation in informal settlements of Quito. Residents of informal settlements are aware of the value that green spaces provide, so they organize politically to take control of neighboring unbuilt areas to create green spaces that enhance their capabilities to access everyday resources. The ability to speed up commuting time to their everyday destinations, to feed their families without carrying debts with local shop keepers, and to pursue a career that leads them to a better future resembles Sen's thoughts of development as freedoms. These findings are relevant for urban planners to lead the transition toward a more sustainable path of development.

Future research should discuss in more depth how green spaces of informal settlements established, what motivates their transformation, and what threats to their preservation merit attention. Also, this study opens the way to further developments on how to address climate change policies, ecosystem services, and nature-based solutions in the context of urban marginalization of fast growing Latin American cities.

\section{References}

Abad, L. A., \& Lindert, P. H. (2017). Fiscal Redistribution in Latin America Since the Nineteenth Century Has Latin American Inequality Changed Direction? (pp. 243-282): Springer. https://doi.org/10.1007/978-3-319-44621-9_11

Adegun, O. B. (2014). Green infrastructure and ecosystem services in informal urban settlements. https://doi.org/10.3846/20297955.2017.1296791

Alova, G., \& Burgess, G. (2017). Housing poverty in Ecuador: challenges to eradication. Survey Review, 49(353), 117-133. https://doi.org/10.1080/00396265.2015.1133519

Auyero, J. (2000). The hyper-shantytown: Neo-liberal violence(s) in the Argentine slum. Ethnography, 1(1), 93-116. http://www.jstor.org/stable/24047730. https://doi.org/10.1177/14661380022230651

Becker, M. (2011). Correa, indigenous movements, and the writing of a new constitution in Ecuador. Latin American Perspectives, 38(1), 47-62. https://doi.org/ $10.1177 / 0094582 X 10384209$

Briant Carant, J. (2017). Unheard voices: a critical discourse analysis of the Millennium Development Goals' evolution into the Sustainable Development Goals. Third World Quarterly, 38(1), 16-41. https://doi.org/10.1080/01436597.2016.1166944

Choguill, C. L. (1996). Ten steps to sustainable infrastructure. Habitat International, 20(3), 389-404. https://doi.org/10.1016/0197-3975(96)00013-6 
Clark, P. (2013). Food sovereignty, post-neoliberalism, campesino organizations and the state in Ecuador. Food Sovereignty: A Critical Dialogue, Yale, CT.

Costanza, R., d'Arge, R., De Groot, R., Farber, S., Grasso, M., Hannon, B., \& Van Den Belt, M. (1997). The value of the world's ecosystem services and natural capital. nature, 387(6630), 253-260. https://doi.org/10.1038/387253a0

Crespo, A. R. V., Puerta, J. M., Corrales, M. E., Stone, L. F., Biau, J., Quintanilla, O., \& Rivera, J. (2016). Documento de enfoque: Evaluación de la Iniciativa Ciudades Emergentes y Sostenibles del BID. shorturl.at/fqGJN on 10/05/2017

Daly, E. (2012). The Ecuadorian exemplar: the first ever vindications of constitutional rights of nature. Review of European Community \& International Environmental Law, 21(1), 63-66. https://doi.org/10.1111/j.1467-9388.2012.00744.x

Davidson-Hunt, I., Idrobo, C., Janzen, A., Kuzivanova, V., Lizáraga, P., Robson, J., \& Vacaflores, C. (2017). Biocultural Design Research Guide.

Davis, M. (2006). Planet of slums. Verso. https://doi.org/10.1177/00219096080430050502

Denscombe, M. (2014) The good research guide: for small-scale social research projects. (5th ed.). Maindenhead: Open University Press.

El Telégrafo. (2014, December 3rd, 2014). El deporte barrial en Quito agrupa a 7600 clubes y 350 ligas [The neighbourhood sport in Quito groups 7600 clubs and 350 leagues]. El Telégrafo. http://www.eltelegrafo.com.ec/noticias/quito/1 1/el-deporte-barrial-en-quito- agrupa-a-7-600-clubes-y-350-ligas-infografia

Greene, N. (2011). The first successful case of the Rights of Nature implementation in Ecuador. The Global Alliance for the Rights of Nature. http://therightsofnature. org/first-ron-case-ecuador.

Hagenaars, A., \& De Vos, K. (1988). The definition and measurement of poverty. Journal of human resources, 211-221. https://doi.org/10.2307/145776

Haque, M. S. (2000). Environmental discourse and sustainable development: Linkages and limitations. Ethics and the Environment, 3-21.

Horn, P. (2017). Indigenous peoples, the city and inclusive urban development policies in Latin America: Lessons from Bolivia and Ecuador. Development Policy Review. https://doi.org/10.1111/dpr.12234

Hycner, R. H. (1985). Some guidelines for the phenomenological analysis of interview data. Human studies, 8(3), 279-303. https://doi.org/10.1007/BF00142995 Jácome, E. (2017a, 8 January 2017). El 60\% de las edificaciones son informales en el Distrito Metropolitano de Quito. El Comercio. http://www.elcomercio.com/actualidad/municipio-quito-regulacion-viviendas-informales.html.

Jácome, E. (2017). Quito, capital provincial con más espacios verdes del país. El Comercio.

Jordán Fuchs, R., Simioni, D., \& degli Affari Esteri, I. M. (2003). Gestión urbana para el desarrollo sostenible en América Latina y el Caribe: CEPAL.

Kaplan, A., Velibeyoğlu, K., Kılıçaslan, Ç., Özeren, M., and İnce, İ. (2013) "Revisiting Urban Brownfield Regeneration and Beyond within the Lens of Green Infrastructure-based Design and Management," Proceedings of the Fábos Conference on Landscape and Greenway Planning. 4(1) https://scholarworks.umass.edu/fabos/vol4/iss1/38 Access 14/05/2019

Kauffman, C. M., \& Martin, P. L. (2014). Scaling up Buen Vivir: globalizing local environmental governance from ecuador. Global Environmental Politics, 14(1), 40-58. https://doi.org/10.1162/GLEP_a_00256

Lossouarn, C., Pangare, V., Fenghua, S., Lentini, E. J., Loftus, T., Dickinson, M. A., \& Phan, T. S. H. (2016). Water, Megacities and Global Change: UNESCO \& ARCEAU-IdF.

Lüthi, C., Panesar, A., Schütze, T., Norström, A., McConville, J., Parkinson, J., \& Action, A. F. (2011). [P.] Sustainable Sanitation in Cities A framework for action.

Mara, D. (1996). Low-cost sewerage: John Wiley. http://shorturl.at/ghH69 Access 19/04/2017

Mara, D., \& Alabaster, G. (2008). A new paradigm for low-cost urban water supplies and sanitation in developing countries. Water Policy, 10(2), 119-129. https://doi.org/10.2166/wp.2008.034

McIntosh, C., Alegria, T., Ordoñez, G., \& Zenteno, R. (2013). Slum Infrastructure Upgrading and Budgeting Spillovers: The Case of Mexico’s Hábitat Program. Conference Proceedings UCSD. http://shorturl.at/gkyzS Access 10/12/2020

McMichael, P. (2011). Development and Social Change: A Global Perspective: A Global Perspective: Sage Publications.

Milou, A. (2008). Stormwater LID alternatives for low income settlements in Central America: The case of Ocotillo Anexo, Honduras. Tufts University.

Mitlin, D., \& Satterthwaite, D. (2013). Urban poverty in the global south: scale and nature: Routledge.

Motzny, A. (2015). Prioritizing vacant properties for green infrastructure. University of Michigan. http://hdl.handle.net/2027.42/113080 Access 11/07/2017

Pereira, A. S., et al. (2018). Metodologia da pesquisa científica. UAB/ NTE/ UFSM. https://repositorio.ufsm.br/bitstream/handle/1/15824/Lic_Com putacao_Metodologia-Pesquisa-Cientifica.pdf?sequence=1 Accessed 12/01/2021

Radcliffe, S. A. (2012). Development for a postneoliberal era? Sumak kawsay, living well and the limits to decolonisation in Ecuador. Geoforum, 43(2), 240249. https://doi.org/10.1016/j.geoforum.2011.09.003

Rashid S. F. (2009). Strategies to reduce exclusion among populations living in urban slum settlements in Bangladesh. Journal of health, population, and nutrition, 27(4), 574-586. https://doi.org/10.3329/jhpn.v27i4.3403 
Research, Society and Development, v. 10, n. 1, e29310111858, 2021

(CC BY 4.0) | ISSN 2525-3409 | DOI: http://dx.doi.org/10.33448/rsd-v10i1.11858

Rueda Carrillo, M. E. (2015). La percepción actual y la calidad del verde en Quito: Un análisis de su potencial de sostenibilidad para responder a los retos de la agenda hábitat. PUCE.

Sen, A. (2001). Development as freedom. Oxford Paperbacks.

Simons, H. (2009). Case study research in practice: SAGE publications.

Thompson, C. W., Roe, J., Aspinall, P., Mitchell, R., Clow, A., \& Miller, D. (2012). More green space is linked to less stress in deprived communities: Evidence from salivary cortisol patterns. Landscape and urban planning, 105(3), 221-229. https://doi.org/10.1016/j.landurbplan.2011.12.015

Verdesoto, L., Donoso, R., Aldaz, R., Valdivieso, L., Marcillo, J., Chalco, S., \& Morochz, I. (2009). Quito, un caleidoscopio de percepciones midiendo la calidad de vida. La calidad de vida.

WHO. (2012). Indicators for Health in Sustainable Cities. Paper presented at the WHO Expert Consultation in the Context of Rio+20 Conference on Sustainable Development, New York, USA. 